\title{
Seismic Behaviour of Exterior Reinforced Concrete Beam-Column Joints in High Performance Concrete Using Metakaolin and Partial Replacement with Quarry Dust
}

\author{
G. R. Vijay Shankar ${ }^{1}$ and D. Suji ${ }^{2}$ \\ ${ }^{1}$ Department of Civil Engineering, Karpagam University, Coimbatore, Tamil Nadu 641 402, India \\ ${ }^{2}$ Department of Civil Engineering, R. V.S. College of Engineering and Technology, Coimbatore, Tamil Nadu 641 021, India \\ Correspondence should be addressed to G. R. Vijay shankar; girivijayshankar@gmail.com
}

Received 15 November 2013; Accepted 5 February 2014; Published 7 April 2014

Academic Editors: J. Foct and H. Yoshihara

Copyright (C) 2014 G. R. V. shankar and D. Suji. This is an open access article distributed under the Creative Commons Attribution License, which permits unrestricted use, distribution, and reproduction in any medium, provided the original work is properly cited.

\begin{abstract}
Recent earthquakes have demonstrated that most of the reinforced concrete structures were severely damaged; the beam-column joints, being the lateral and vertical load resisting members in reinforced concrete structures, are particularly vulnerable to failures during earthquakes. The existing reinforced concrete beam-column joints are not designed as per code IS13920:1993. Investigation of high performance concrete (HPC) joints with conventional concrete (CC) joints (exterior beam-column) was performed by comparing various reinforcement detailing schemes. Ten specimens were considered in this investigation and the results were compared: four specimens with CC (with and without seismic detailing), four specimens with HPC (with and without seismic detailing), and two specimens with HPC at confinement joint. The test was conducted for lateral load displacement, hysteresis loop, load ratio, percent of initial stiffness versus displacement curve, total energy dissipation, strain in beam main bars, and crack pattern. The results reveal that HPC with seismic detailing will be better compared with other reinforcements details under cyclic loading and reverse cyclic loading.
\end{abstract}

\section{Introduction}

Earthquakes present a threat to public safety and welfare in a significant portion everywhere. We cannot stop earthquakes, but we can protect ourselves from them, as "earthquakes do not kill human beings, but the structures do." The behaviour of reinforced concrete moment resisting frame structures in recent earthquakes all over the world has highlighted the consequences of poor performance of beam-column joints. Beam-column joints in a reinforced concrete moment resisting frame are crucial zones for transfer of loads effectively between the connecting elements (i.e., beams and columns) in the structure. In the analysis of reinforced concrete moment resisting frames, the joints are generally assumed as rigid. In Indian practice, the joint is usually neglected for specific design with attention being restricted to provision of sufficient anchorage for beam longitudinal reinforcement. This may be acceptable when the frame is not subjected to earthquake loads. The poor design practice of beamcolumn joints is compounded by the high demand imposed by the adjoining flexural members (beams and columns) in the event of mobilizing their inelastic capacities to dissipate seismic energy.

For the past three decades, extensive research has been carried out on studying the behaviour of joints under seismic conditions through experimental and analytical studies. Various international codes of practices have been undergoing periodic revisions to incorporate the research findings into practice. This thesis aims to add to that body of knowledge through experimental investigation on the behaviour of beam-column joint under seismic loading.

\section{Experimental Investigation}

2.1. Details of Test Specimen. The test specimen was reduced to one-fourth scale to suit the loading arrangement and test 


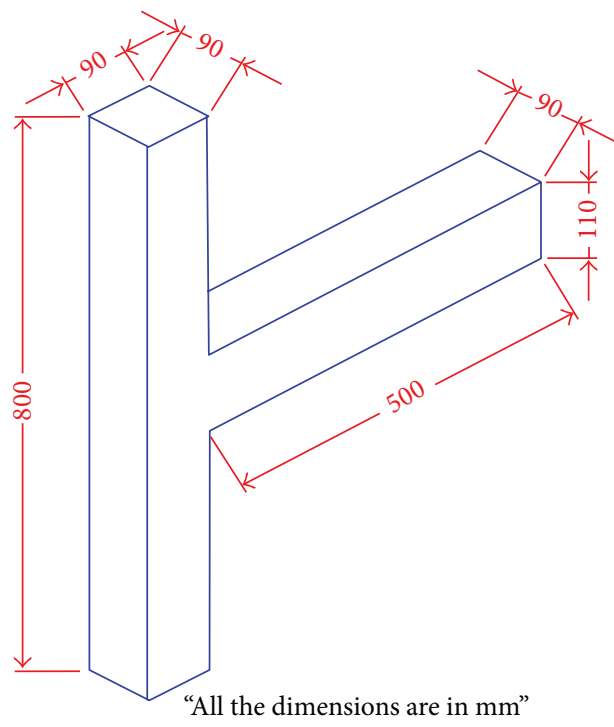

FIGURE 1: Overall dimensions of test specimens.

facilities. Four numbers of 8 unloaded and beamwas meter bars were used for main bars in column and 3 numbers of $8 \mathrm{~mm}$ Diameter were used for top reinforcement and 2 numbers of $8 \mathrm{~mm}$ Diameter were used for bottom reinforcement in beams. The dimensions of beam were $110 \mathrm{~mm} \times$ $90 \mathrm{~mm}$ and those of column were $90 \times 90 \mathrm{~mm}$. All specimens were cut at midheight of supporting column and at midspan of beams, which were the assumed points of inflection. Figure 1 shows a sketch of test specimens with overall dimensions. And Figure 2 shows the various reinforcement detailing schemes.

\subsection{Materials}

(i) Cement. Ordinary Portland cement of grade 53 conforming to IS specifications was used to cast the test specimen.

(ii) Water. Potable water available in the campus was used for mixing and curing of concrete.

(iii) Fine Aggregate. Fine aggregate used for all the specimens was river sand. The fine aggregate used for casting was sieved through IS $4.75 \mathrm{~mm}$ sieve.

(iv) Coarse Aggregate. To suit the needs of scale of test specimen, small size of coarse aggregate was used. The coarse aggregate used was passed through IS $10 \mathrm{~mm}$ sieve.

(v) Metakaolin. Metakaolin (MK) is produced by heattreating kaolin, one of the most abundant natural minerals.

(vi) Quarry Dust. Quarries and aggregate crushers are basic requisites for construction industry and quarry dust is a by-product of rubble crusher units.

(vii) Super Plasticizer. For processing HPC, the most important chemical admixture is the super plasticizer, which is the high-range water-reducing admixture.

\subsection{Compressive Strength of Concrete. See Table 2.}

2.4. Steel. The main reinforcement used for the specimen was tor steel of diameter of $8 \mathrm{~mm}$. The shear reinforcement was mild steel of diameter of $3.3 \mathrm{~mm}$. Specimens of $300 \mathrm{~mm}$ length were cut out and tested in computerized UTM to obtain the tensile strength. The test results of the specimen are shown in Table 3.

\section{Description of the Form Work}

To cast the specimen, four wooden moulds were fabricated. The size of the beam was $500 \mathrm{~mm} \times 90 \mathrm{~mm} \times 110 \mathrm{~mm}$ and the column size was $800 \mathrm{~mm} \times 90 \mathrm{~mm} \times 90 \mathrm{~mm}$, shown in Figure 3 . The moulds were nailed to a base plate, in order to keep the alignment accurately.

\subsection{Reinforcement Details}

3.1.1. Reinforcement Cage of Ordinary Joint. The reinforcement details and reinforcement cage of the ordinary joint are shown in Figure 4. The main reinforcement provided in the beam was $8 \mathrm{~mm}$ diameter bars, 3 numbers at top and 2 numbers at bottom. The stirrups are $3.3 \mathrm{~mm}$ diameter bars at $20 \mathrm{~mm} \mathrm{c} / \mathrm{c}$ for a distance of $2 \mathrm{~d}$, that is, $220 \mathrm{~mm}$ from the face of the column, and at $40 \mathrm{~mm} \mathrm{c} / \mathrm{c}$ for remaining length of the beam.

3.1.2. Reinforcement Cage of Seismic Detail Joint. The reinforcement details and reinforcement cage of the test specimen are shown in Figure 5. The main reinforcement provided in the beam was $8 \mathrm{~mm}$ diameter bars, 3 numbers at top and 2 numbers. at bottom. The stirrups are $3.3 \mathrm{~mm}$ diameter bars at $40 \mathrm{~mm} \mathrm{c} / \mathrm{c}$ spacing.

\section{Casting and Curing}

The moulds are arranged properly and placed over a smooth surface. The sides of the mould exposed to concrete were oiled well to prevent the side walls of the mould from absorbing water from concrete and to facilitate easy removal of the specimen. The reinforcement cages were placed in the moulds and cover between cage and form provided was $10 \mathrm{~mm}$. Cement mortar block pieces were used as cover blocks. The concrete contents such as cement, sand, aggregate, metakaolin, quarry dust, super plasticizer, and water were weighed accurately and mixed. The mixing was done till uniform mix was obtained. The concrete was placed into the mould immediately after mixing and was well compacted. It is shown in Figures 6 and 7. The test specimens were demoulded at the end of 24 hours of casting (Table 1). They were marked identifications. They were cured in water for 28 days. After 28 days of curing the specimen was dried in air and whitewashed.

\section{Test Setup and Instrumentation}

All the specimens were tested in a reaction frame of 50 tons of capacity. The test setup is shown in Figures 8 and 9; hydraulic 
TABLE 1: Details of test specimens.

\begin{tabular}{|c|c|c|c|}
\hline Sl. number & Specimens ID & Description of test specimens & $\%$ of metakaolin and quarry dust \\
\hline 1 & $\mathrm{O} 1 \& \mathrm{O} 2$ & $\begin{array}{c}\text { Conventional concrete } \\
\text { (without seismic detailing) }\end{array}$ & - \\
\hline 2 & SS1 \& SS2 & $\begin{array}{l}\text { Conventional concrete } \\
\text { (with seismic detailing) }\end{array}$ & - \\
\hline 3 & E11 \& E12 & $\begin{array}{l}\text { High performance concrete } \\
\text { (without seismic detailing) }\end{array}$ & $\begin{array}{c}\text { Normal concrete }+10 \% \text { metakaolin }+ \\
30 \% \text { quarry dust }\end{array}$ \\
\hline 4 & $\mathrm{E} 21 \& \mathrm{E} 22$ & $\begin{array}{l}\text { High performance concrete } \\
\text { (with seismic detailing) }\end{array}$ & $\begin{array}{c}\text { Normal concrete }+10 \% \text { metakaolin }+ \\
30 \% \text { quarry dust }\end{array}$ \\
\hline 5 & $\mathrm{E} 31 \& \mathrm{E} 32$ & $\begin{array}{l}\text { High performance concrete } \\
\text { (with seismic detailing) (confinement } \\
\text { joint) }\end{array}$ & $\begin{array}{c}\text { Normal concrete }+10 \% \text { metakaolin }+ \\
30 \% \text { quarry dust }\end{array}$ \\
\hline
\end{tabular}

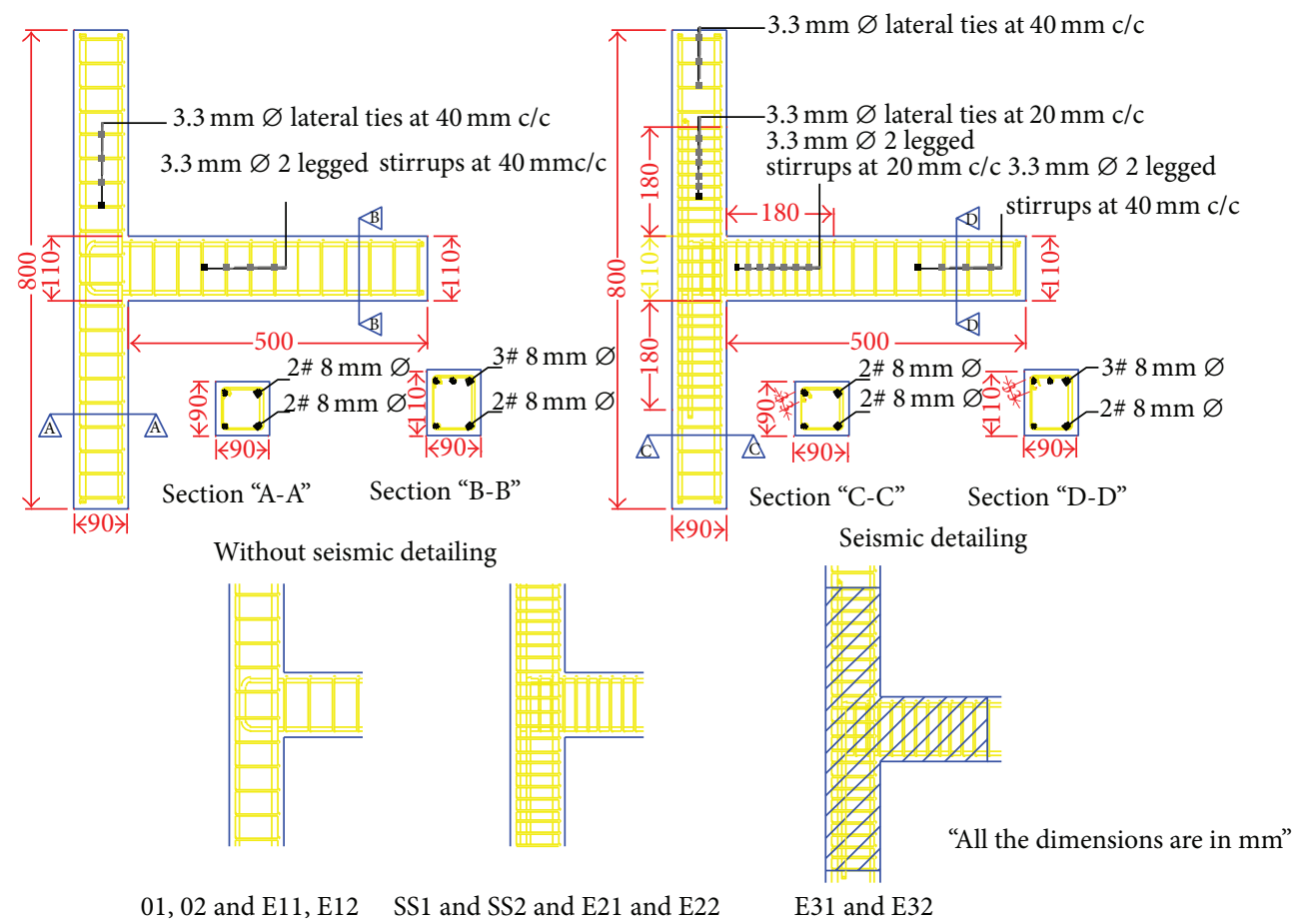

FIGURE 2: Various schemes of reinforcement detailing.

TABle 2: Cube compressive strength details.

\begin{tabular}{lc}
\hline Type & $\begin{array}{c}\text { Compressive strength of } \\
\text { cube }\left(\mathrm{N} / \mathrm{mm}^{2}\right)\end{array}$ \\
\hline $\begin{array}{l}\text { Conventional concrete M40 } \\
\text { High performance concrete } \\
\text { (M40) with 10\% metakaolin }+\end{array}$ & 45.67 \\
$30 \%$ quarry dust mix & 51.34 \\
\hline
\end{tabular}

jack was used to apply the load at the free end of the beam in both upward and downward directions individually. To record the load precisely a proving ring was used. The load is applied in cyclic and reverse cyclic manners and measured for every $5 \mathrm{~mm}$ deflection. The deflection of the beam at the point of loading during test was measured as $5 \mathrm{~mm},-5 \mathrm{~mm}$,
$10 \mathrm{~mm},-10 \mathrm{~mm}$, and $15 \mathrm{~mm}$, respectively. Reversal loading is noted for every decrease in deflection.

5.1. Measurement of Joint Distortion. Dial gauge D6 was fixed diagonally in the opposite direction in the joint region. It is used to measure the joint distortion.

5.2. Measurement of Strains. Mechanical and digital strain gauges were used to measure strain in reinforcement bars. Gauge length of mechanical strain is $100 \mathrm{~mm}$. Demec points were fixed in position for the measurement of strains.

\section{Loading History}

The exterior beam-column joint specimen was subjected to cyclic loading and reverse cyclic loading simulating earthquake loads. The displacement sequence consists of $5 \mathrm{~mm}$, 
TABLE 3: Properties of reinforcements.

\begin{tabular}{lccccc}
\hline Sl. number & Description & Yield load $(\mathrm{kN})$ & Ultimate load $(\mathrm{kN})$ & Ultimate stress $\left(\mathrm{N} / \mathrm{mm}^{2}\right)$ & Yield stress $\left(\mathrm{N} / \mathrm{mm}^{2}\right)$ \\
\hline 1 & $8 \mathrm{~mm}$ bar & 21 & 26.9 & 353.09 & 417.73 \\
2 & $3.3 \mathrm{~mm}$ bar & 1.42 & 2.9 & 341.36 & 166 \\
\hline
\end{tabular}

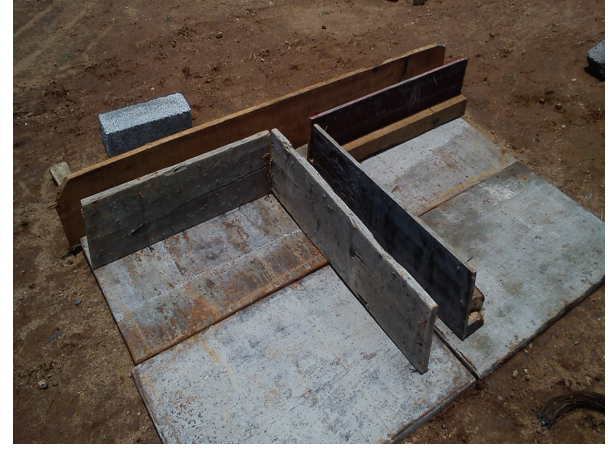

FIGURE 3: Form work of the test specimens.

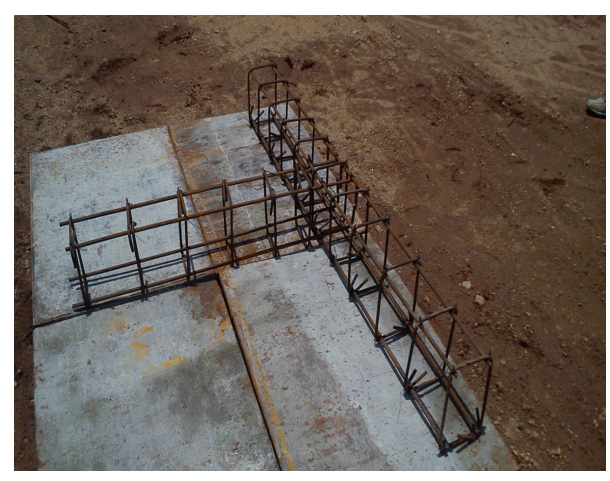

FIgURE 4: Reinforcement cage of ordinary joint.

$-5 \mathrm{~mm}, 10 \mathrm{~mm},-10 \mathrm{~mm}, 15 \mathrm{~mm},-15 \mathrm{~mm}, 45 \mathrm{~mm}$, and $-45 \mathrm{~mm}$. Each displacement level is indicated in dial gauge and corresponding loads are noted from the proving ring. In the first cycle, beam was loaded gradually up to $5 \mathrm{~mm}$ deflection and then unloaded. The beam was loaded gradually up to $-5 \mathrm{~mm}$ deflection and then unloaded the second cycle, beam was loaded gradually up to $10 \mathrm{~mm}$ and then unloaded and beam was loaded gradually up to $-10 \mathrm{~mm}$ and then unloaded similarly each cycle of load is applied.

\section{Load versus Displacement Cycle}

The load versus displacement cycle is drawn for every specimen (Figure 18); the load is noted for $5 \mathrm{~mm}$ displacement, for each cyclic and reverse cyclic loading. The reversal of loading is noted from the proving ring. Figures 10 to 14 show the hysteresis loop for all the specimens.

\section{Load versus Displacement}

Cycle for $\mathrm{O} 1$ and $\mathrm{O} 2$. See Figure 10.

Cycle for SS1 and SS2. See Figure 11.

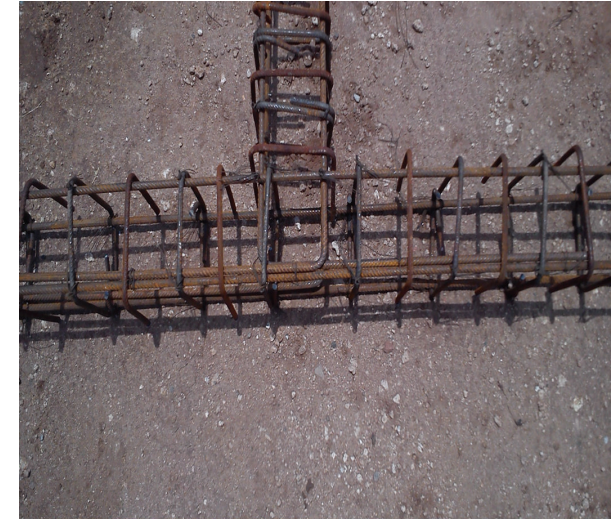

FIGURE 5: Reinforcement cage of seismic detailed joint.

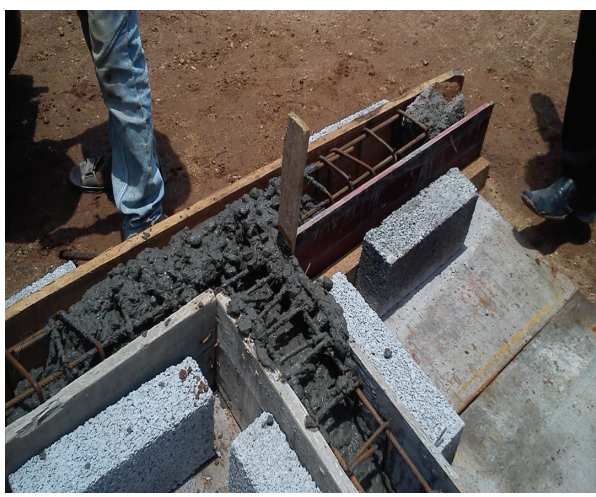

Figure 6: Confinement joint concrete.

Cycle for E11 and E12. See Figure 12.

Cycle for E21 and E22. See Figure 13.

Cycle for E31 and E32. See Figure 14.

Figures 10 to 14 show the variation of load versus displacement cycle for various beam-column joints with various combinations at beam end displacement. The area for each hysteresis loop was calculated using these figures. From Figure 13 it is inferred that specimens E21 and E22 have a load carrying capacity $(23 \mathrm{kN})$ higher than the ordinary beamcolumn joint.

\section{Energy Dissipation}

Energy Dissipation versus Deflection. Figure 15 shows the energy dissipated at each cycle for various specimens. The energy dissipation capacity is calculated using the enclosed area of the load deformation curve during each cycle of 


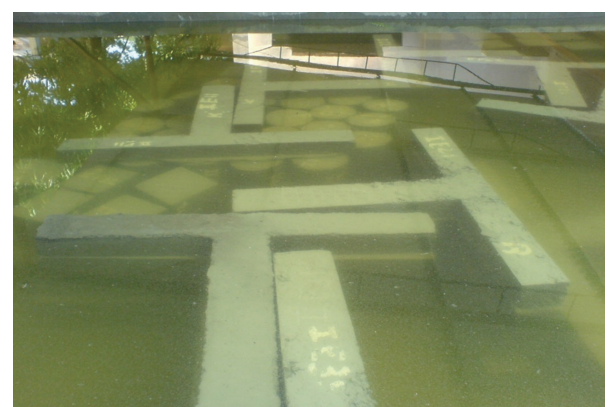

Figure 7: Curing the specimens.

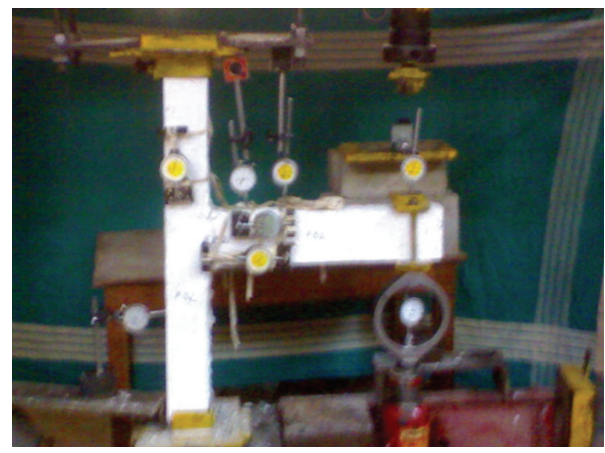

FIGURE 8: Test setup for cyclic load.

loading (i.e., area of each hysteresis loop). From this figure it is inferred that energy dissipation for E21 and E22 (10\% metakaolin $+30 \%$ quarry dust) is more than other specimens.

\section{Beam and Column Reinforcement Strain}

To measure the beam and column strain, (Figures 16 and 17) Demec strain gauge was placed in the beam bottom reinforcement and in the column top outer face reinforcement. The gauge length of $100 \mathrm{~mm}$ was maintained for all the specimens to fix the strain gauge. For specimens O2, SS2, E12, and E32 the yield strain occurs at $5 \mathrm{~mm}$ (1st cycle) and ultimate strain at $-30 \mathrm{~mm}$ (4th cycle). In specimen E22, yield strain occurs at $5 \mathrm{~mm}$ (1st cycle) and ultimate strain at $45 \mathrm{~mm}$ (5th cycle). Demec strain gauge was used to measure the strain in column top outer reinforcement. For specimens $\mathrm{O} 2$ and E22 the yield strain occurs at $10 \mathrm{~mm}$ (2nd cycle) and ultimate strain at $30 \mathrm{~mm}$ (4th cycle). In specimens E12 and E32 yield strain occurs at $5 \mathrm{~mm}$ (1st cycle) and ultimate strain at $-30 \mathrm{~mm}$ (4th cycle). In specimen SS2 yield strain occurs at $-5 \mathrm{~mm}$ (1st cycle) and ultimate strain at $30 \mathrm{~mm}$ (4th cycle).

\section{Ductility}

Ductility is an important characteristic of any structural element. It is described as the capacity of a structural element to undergo deformation beyond yield without losing much of the load carrying capacity. Any type of brittle failure should be avoided, as it does not show warning before failure. If the structure posses sufficient ductile behaviour, it will be

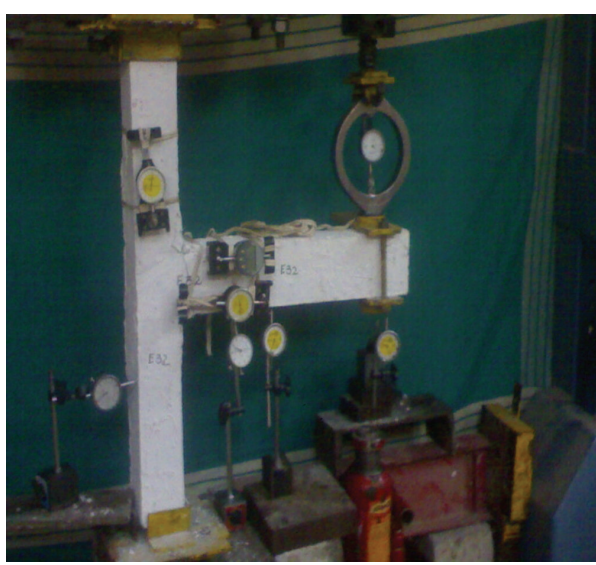

FIGURE 9: Test setup for reverse cyclic load.

able to experience large deformation near ultimate loads. The amount of this inelastic deformation is proportional to the amount of ductility of the member. Ductility has generally been measured by a ratio called ductility factor. It is usually expressed as a ratio of deflection $(\Delta)$ at failure to the corresponding property at yield, as shown below:

displacement ductility factor $\mu \Delta=\Delta u / \Delta y$, where $\Delta u$ is ultimate displacement and $\Delta y$ is yield displacement.

Increase in deformations after reaching ultimate load condition was not considered during experimentation. Hence the deformations at ultimate load have only been considered. The values of displacement ductility factor are calculated from experimental readings and listed in Table 4.

The ductility for the various proportions was calculated and presented in Table 4. It is observed that the ductility property for the beam-column joint with mix is more comparing to other specimens. The exterior beam-column joint E21 and E22 with more ductility factor compared to the all other specimens.

\section{Crack Pattern}

In the beam-column joints, compression and tension developed in joint region during cyclic loading and the bond between concrete and reinforcement was reduced consequently. The first crack occurred near the beam-column joint and with further increase in loading the cracks propagated and initial cracks started widening. The crack pattern of the specimens will be discussed below.

Figure 19 shows the crack pattern for ordinary joint. In this the first crack occurred vertically at $7 \mathrm{~mm}$ deflection in the second cyclic loading, when load was applied at the bottom of the beam. The second crack occurred at $-10 \mathrm{~mm}$ deflection at the third reverse cycle of loading. The third crack occurred diagonally at beam-column joint at $25 \mathrm{~mm}$ deflection at the fourth cycle of loading. The major crack occurred at joint region at $40 \mathrm{~mm}$ deflection at the fifth cycle of loading.

Figure 20 shows the crack pattern for the seismic detailed joint. In this joint, while applying the second cycle loading, 
TABLE 4: Displacement ductility factor.

\begin{tabular}{lcccc}
\hline Sl. number & Specimen ID & Yield $\Delta y(\mathrm{~mm})$ & $\begin{array}{c}\text { Displacement } \\
\text { Ultimate } \Delta u(\mathrm{~mm})\end{array}$ & Ductility factor $\mu \Delta$ \\
\hline 1 & O1 & 17.0 & 40 & 39 \\
2 & O2 & 16.0 & 45 & 2.35 \\
3 & SS1 & 15.0 & 45 & 3.00 \\
4 & SS2 & 14.5 & 45 & 3.10 \\
5 & E11 & 13.0 & 45 & 3.46 \\
6 & E12 & 12.0 & 42 & 3.81 \\
7 & E21 & 11.0 & 43 & 3.64 \\
8 & E22 & 11.5 & 44 & 3.26 \\
9 & E31 & 12.5 & 42 & 3.34 \\
10 & E32 & 13.5 & 4 & \\
\hline
\end{tabular}

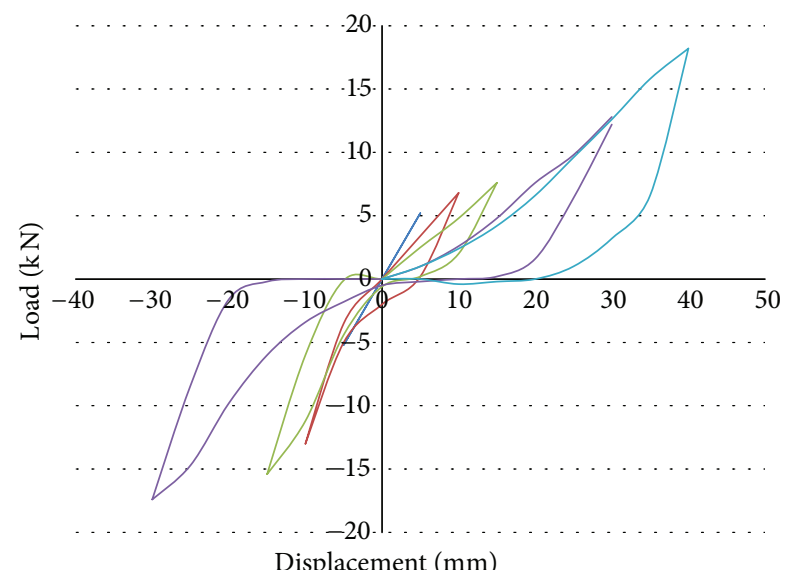

Displacement (mm)

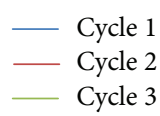

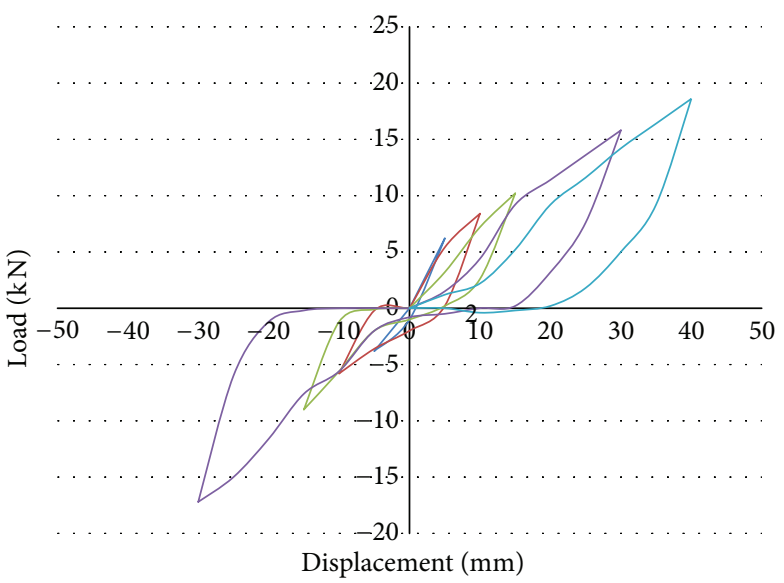

$\begin{array}{ll}\text { Cycle } 1 & \text { Cycle } 4 \\ \text { Cycle } 2 & \text { Cycle } 5\end{array}$

Figure 10: Load versus displacement cycle for $\mathrm{O} 1$ and $\mathrm{O} 2$.

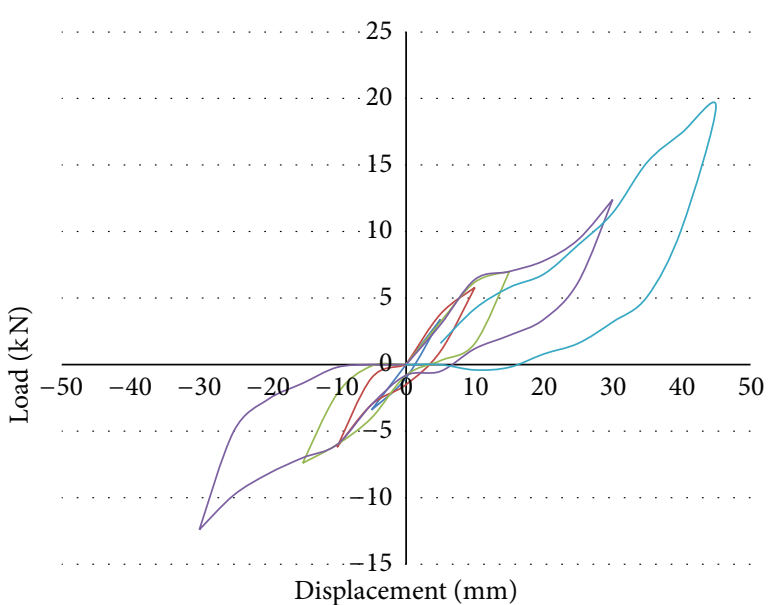

Displacement (mm)

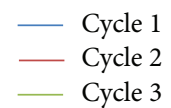

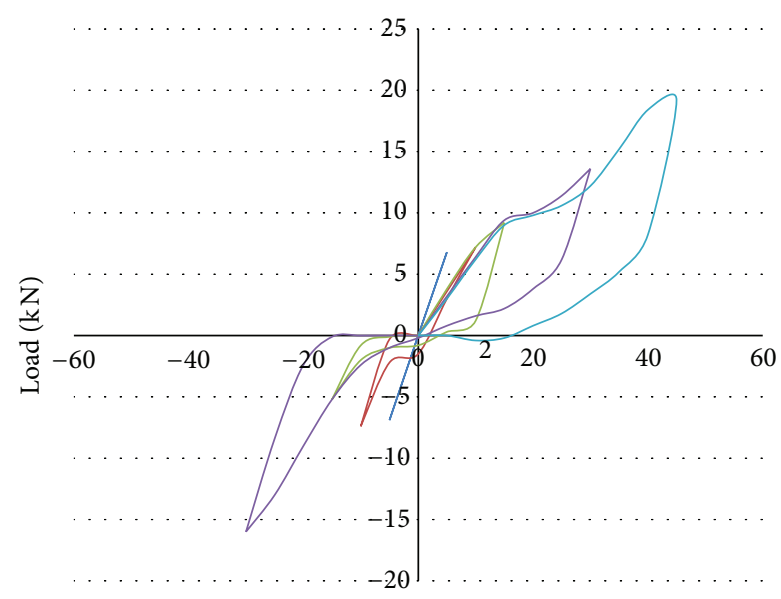

Displacement (mm)

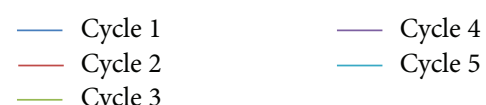

FIGURE 11: Load versus displacement cycle for SS1 and SS2. 


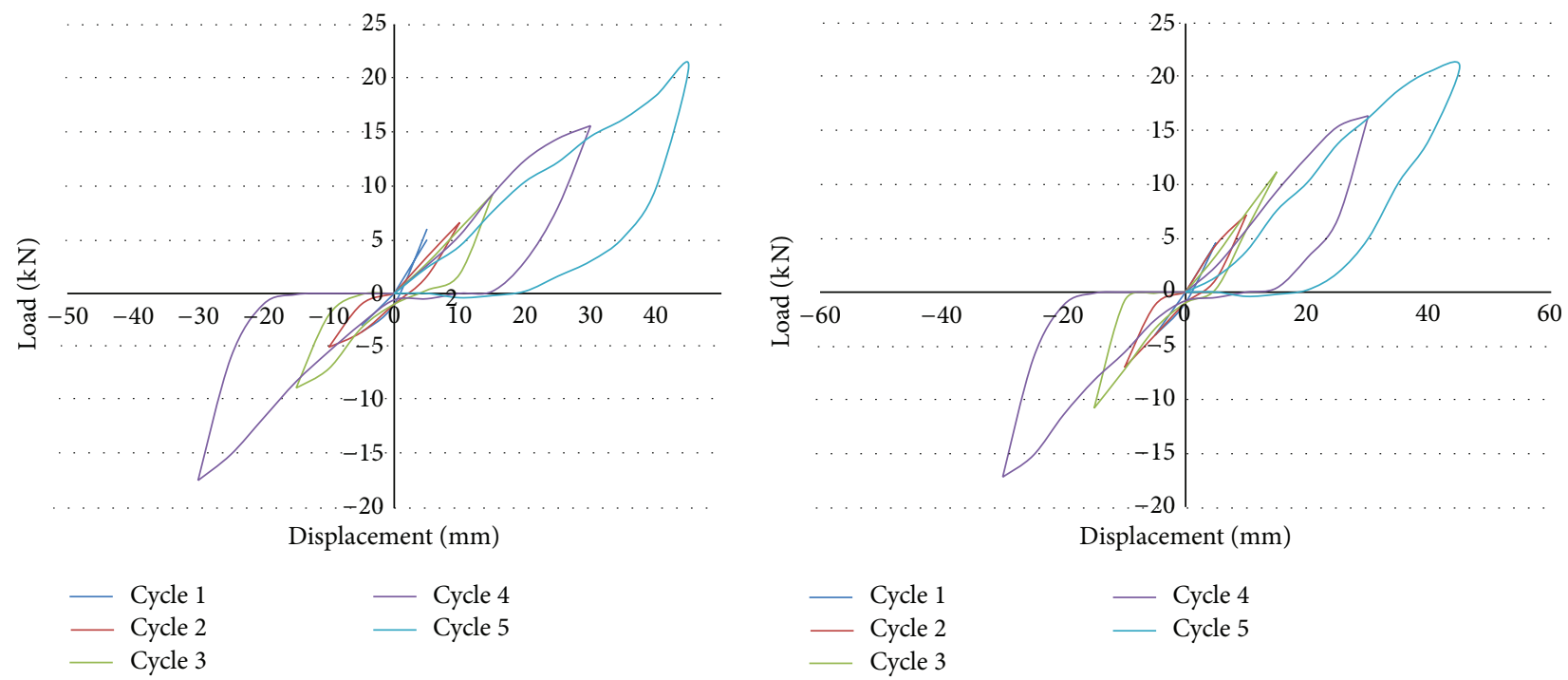

FIGURE 12: Load versus displacement cycle for E11 and E12.
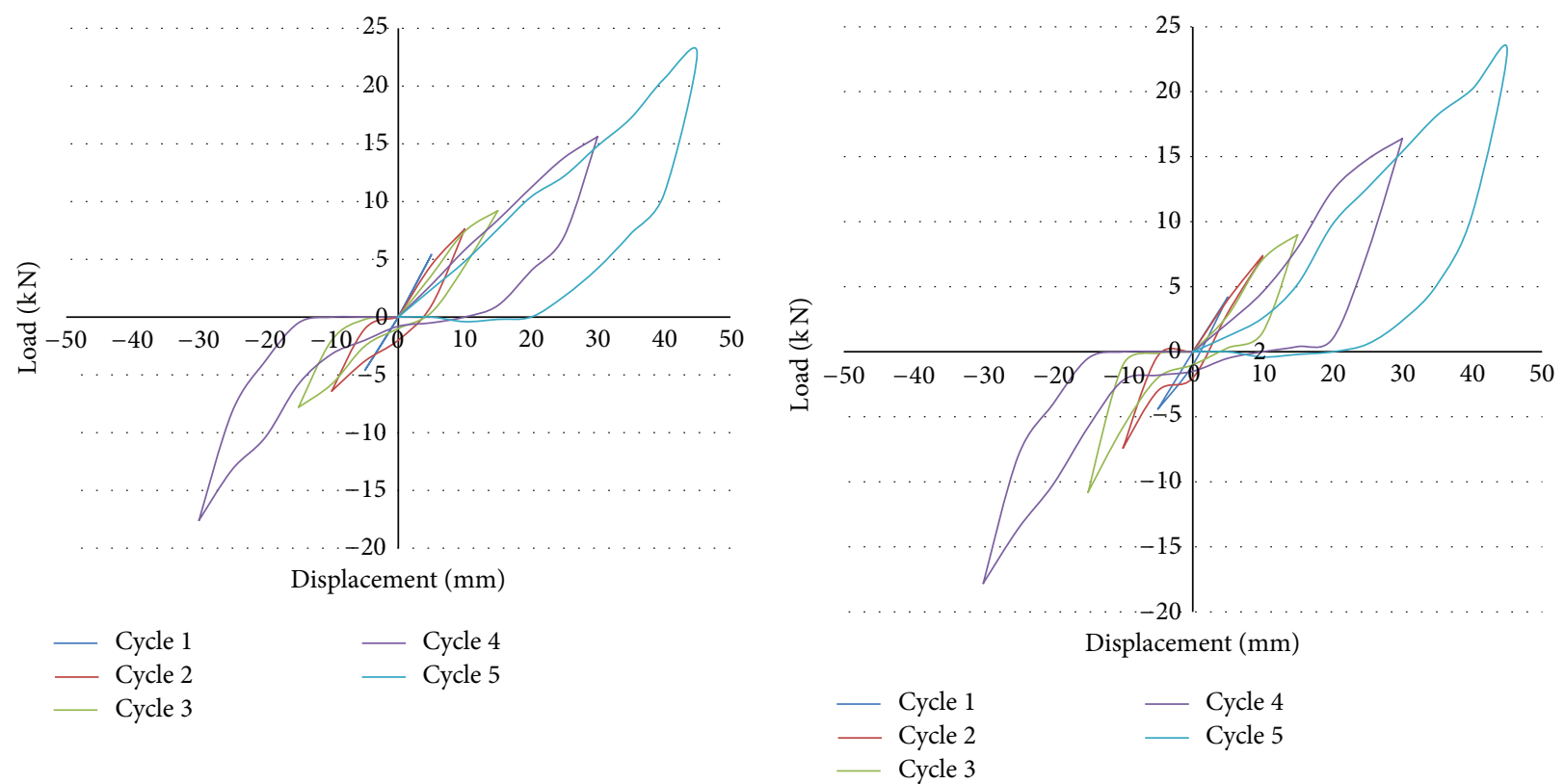

FIGURE 13: Load versus displacement cycle for E21 and E22.

the first crack occurred vertically at $5 \mathrm{~mm}$ deflection in the second cyclic loading. The second crack occurred at $-15 \mathrm{~mm}$ deflection at the third reverse cycle of loading. The third crack occurred diagonally at beam-column joint in $30 \mathrm{~mm}$ deflection at the fourth cycle of loading. The major crack occurred at joint region in $45 \mathrm{~mm}$ deflection at the fifth cycle of loading. In this joint the crack width is small compared to ordinary joint, so it behaves better than ordinary joint.

By comparing Figures 19, 20, 21, and 22, we can observe that the width of the crack is reduced and the ductility is increased as showed in Table 4. From Figures 19 and 22 the second, third, and fourth cracks were only hair cracks. In the metakaolin + quarry dust specimens closely spaced finer cracks were developed and width of such cracks was smaller than that developed in conventional reinforced concrete joint. It was observed that the use of metakaolin and quarry reinforced specimens concrete in the joint core could increase the joint stiffness and minimise damage to the concrete.

By comparing Figures 19 to 23, we can observe that in ordinary specimens wide cracks were developed at the joint and the crack width was more concentrated at the joint. But in metakaolin and quarrydust reinforced specimens in 

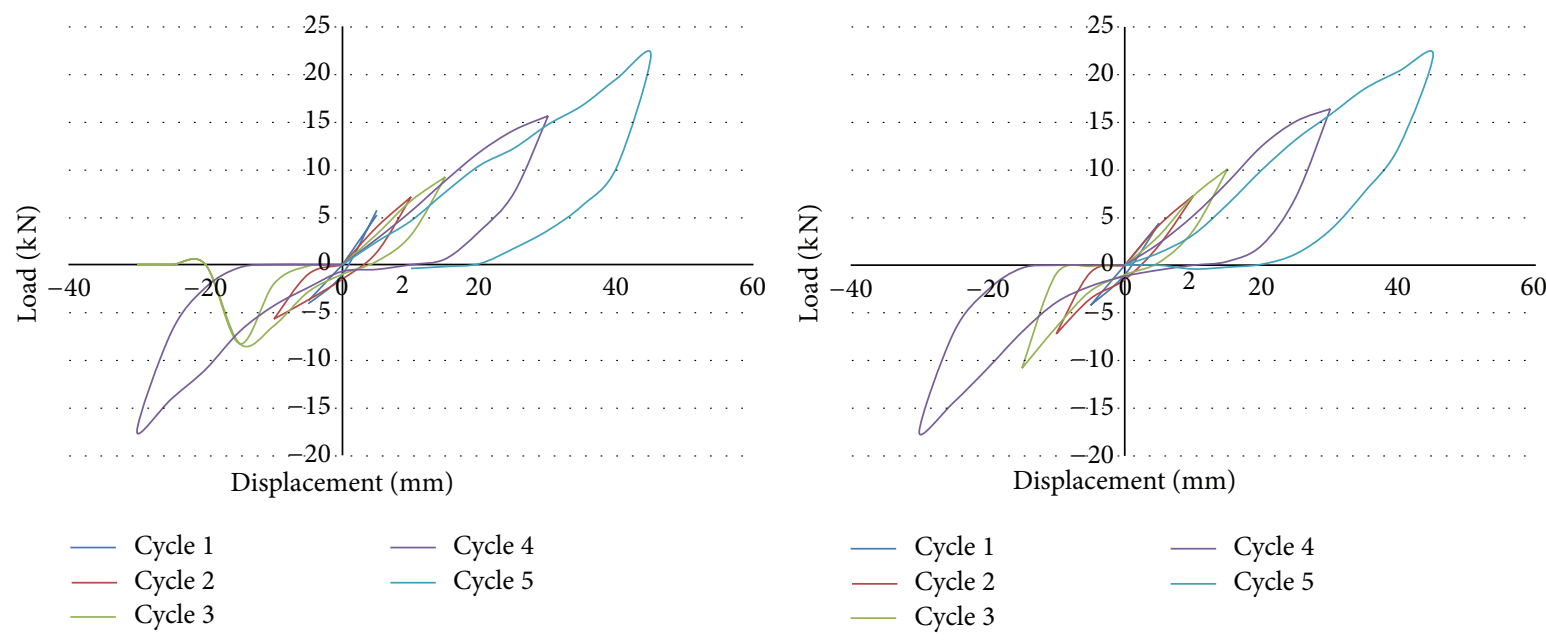

FIGURE 14: Load versus displacement cycle for E31 and E32.

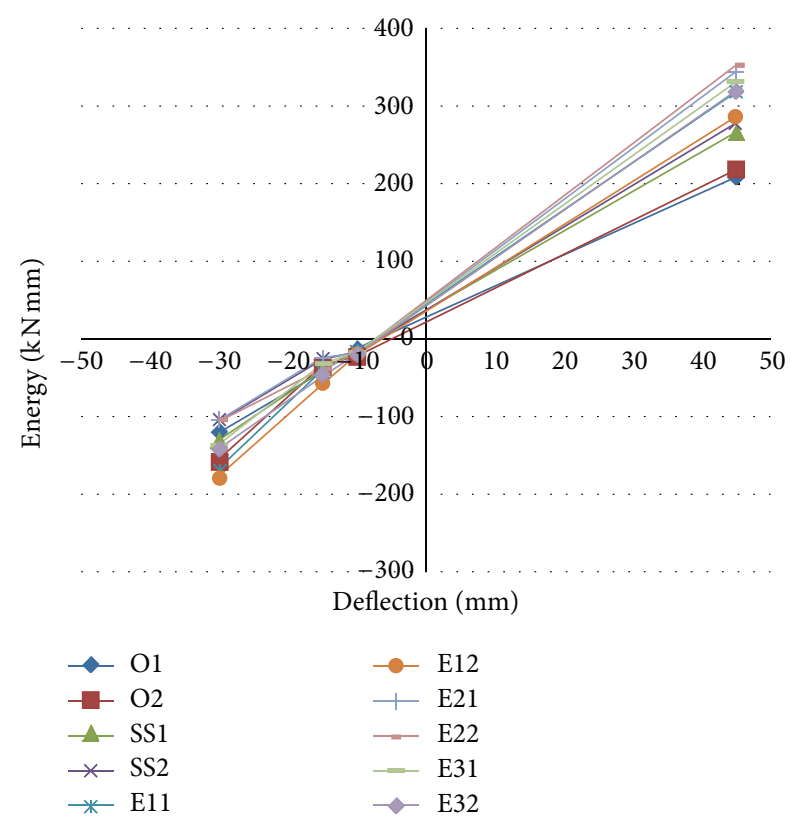

FigURE 15: Energy dissipation versus displacement.

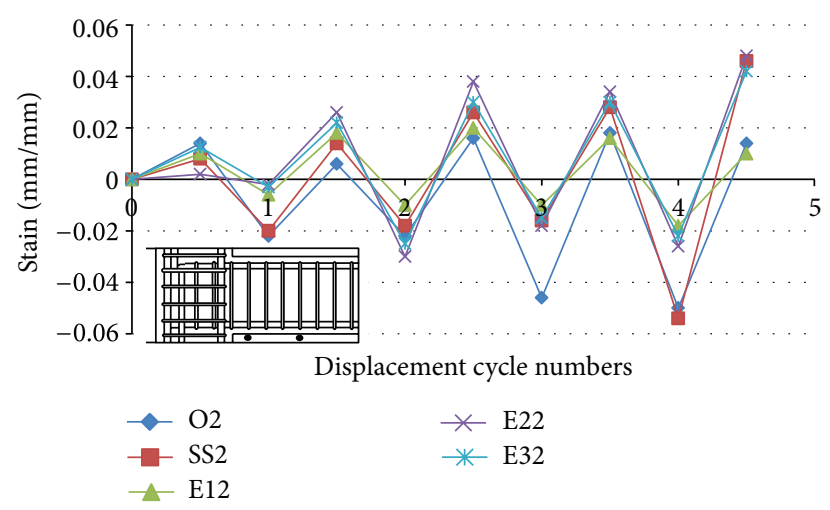

FIGURE 16: Beam bottom reinforcement strain versus cycle number.

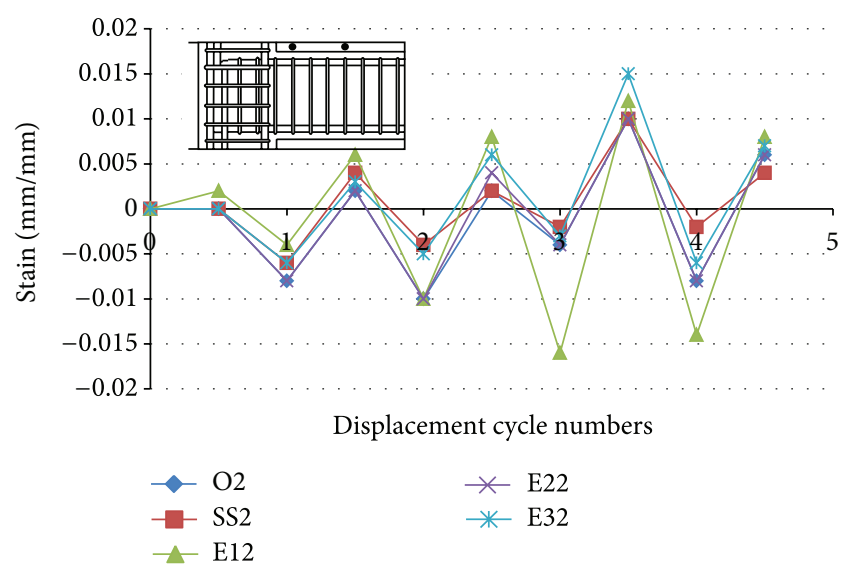

Figure 17: Column top reinforcement strain versus cycle number.

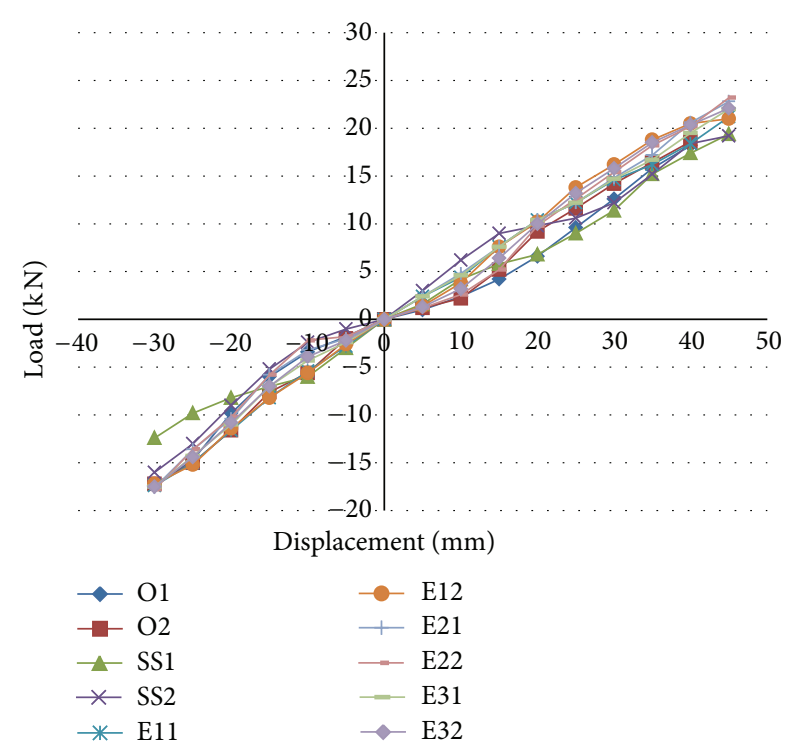

FIgURE 18: Load versus displacement curve. 

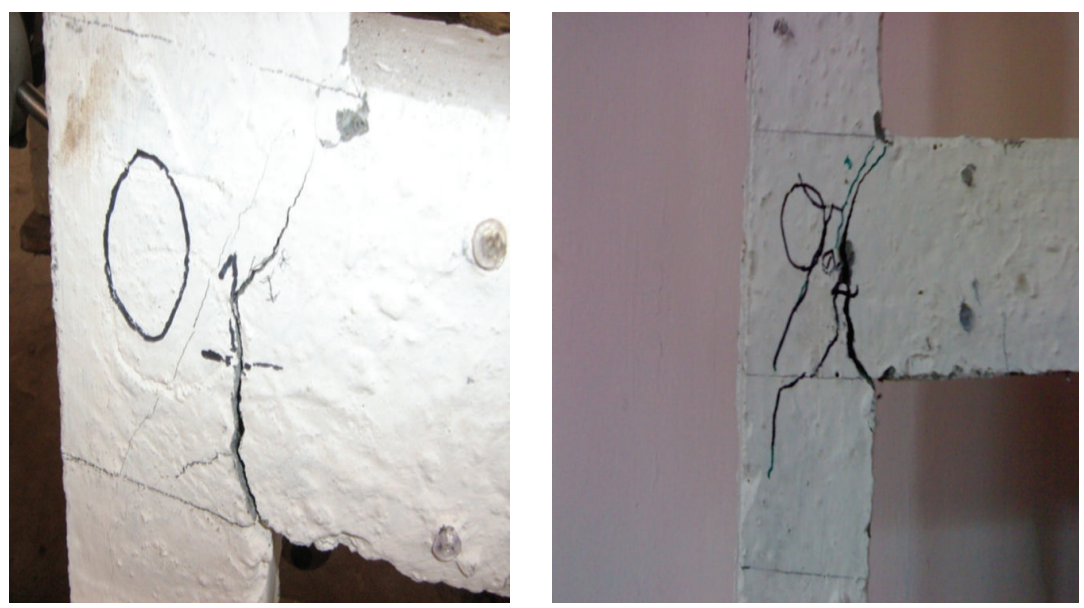

FIGURE 19: Crack pattern for ordinary joint (O1 and $\mathrm{O} 2)$.
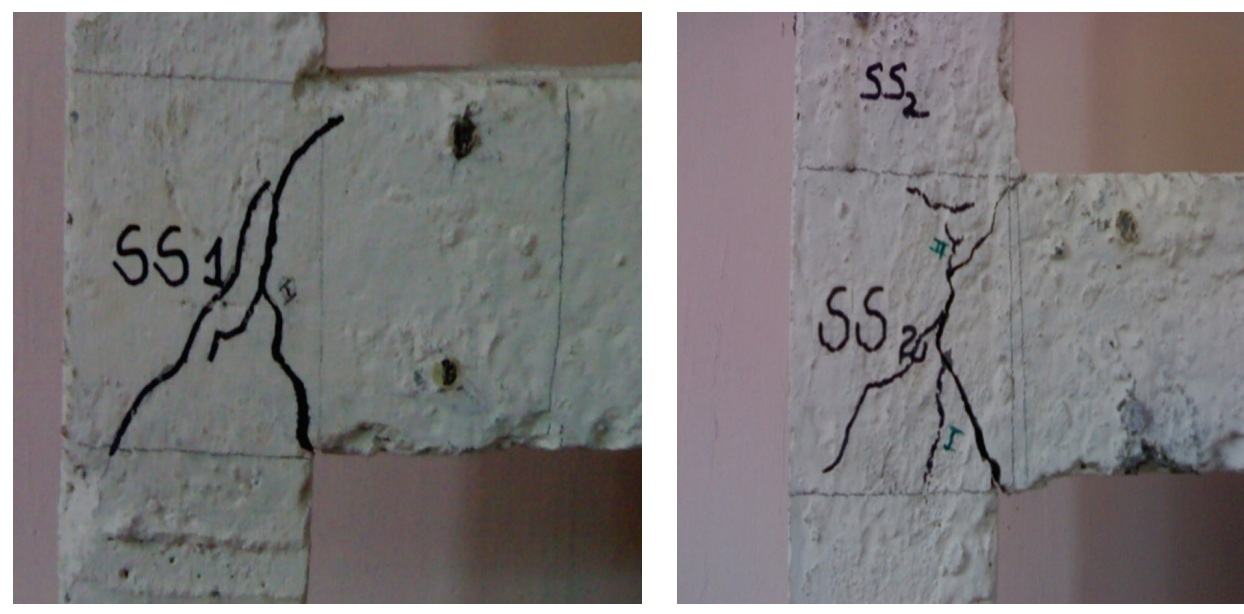

FIGURE 20: Crack pattern for seismic joint (SS1 and SS2).
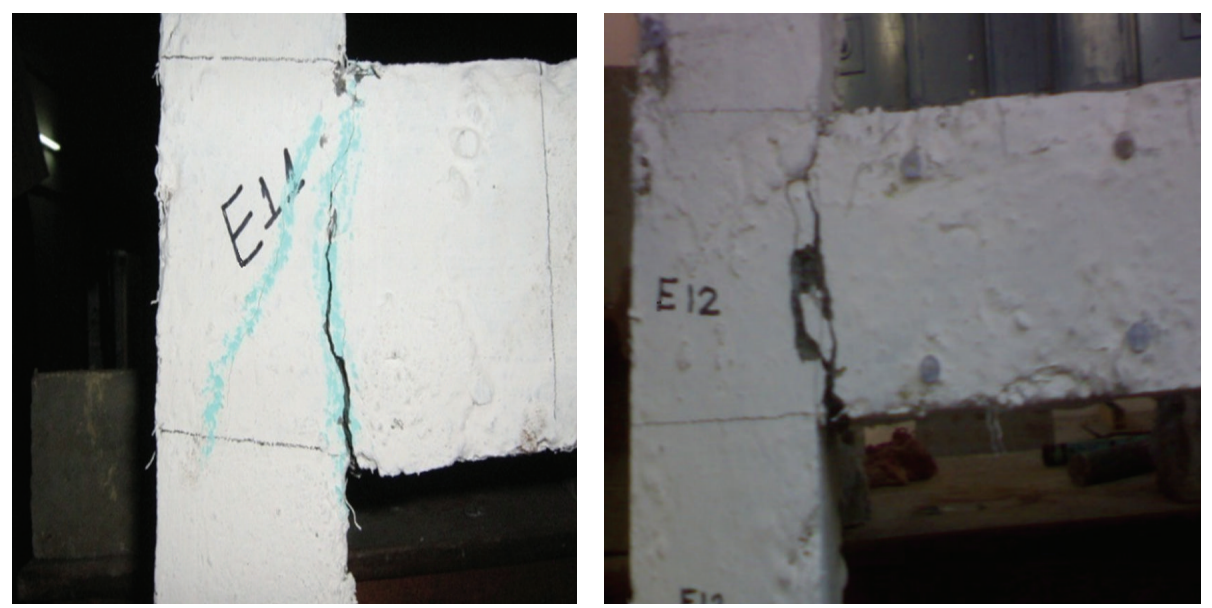

FIGURE 21: Crack pattern for joint with 10\% metakaolin + 30\% quarry dust (E11 and E12). 

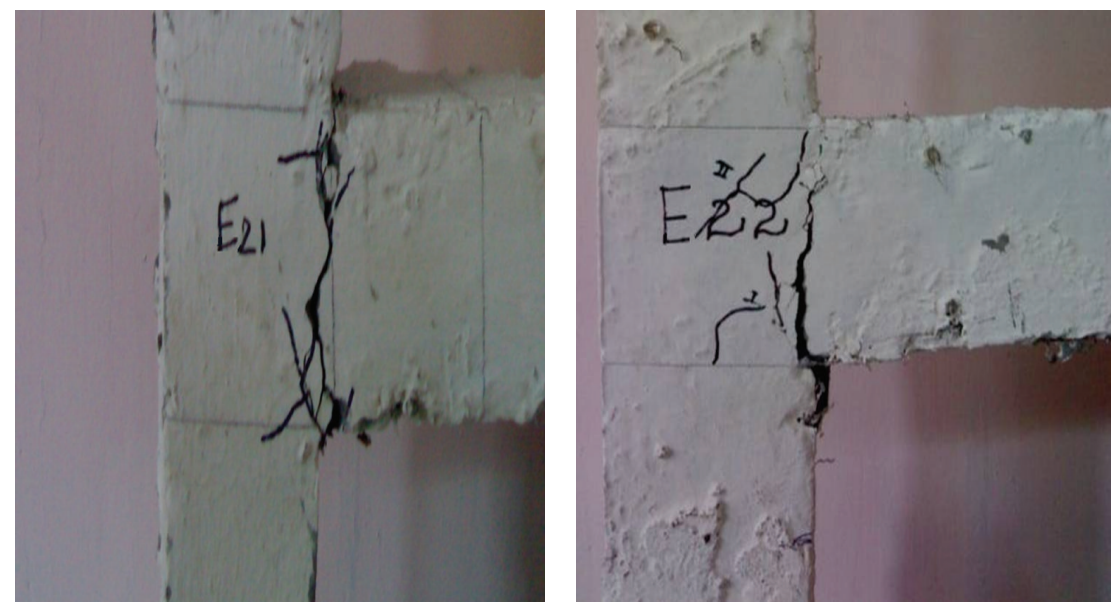

FIGURE 22: Crack pattern for joint with 10\% metakaolin + 30\% quarry dust (E21 and E22).
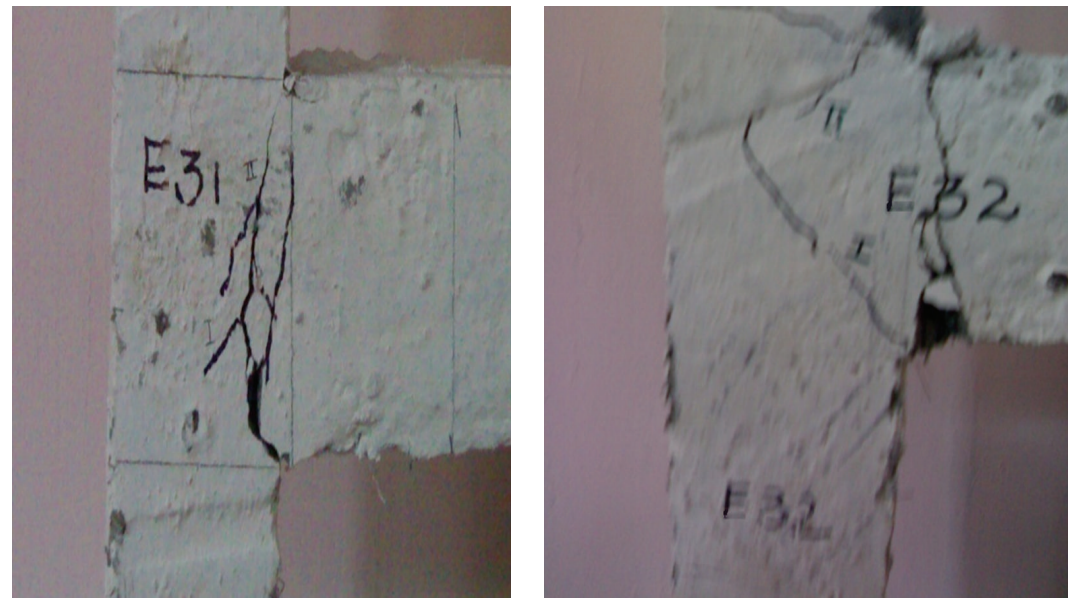

FIGURE 23: Crack pattern for joint with 10\% metakaolin $+30 \%$ quarry dust (E31 and E32).

Confiement joint concrete confined exhibts finer cracks were developed and width of such cracks was smaller than those developed in conventional reinforced concrete joint.

\section{Joint Distortion}

The dial gauge was used for measuring joint distortion in beam-column joint while applying cyclic load. The joint distortion is calculated from the formula

$$
\text { Joint distortion }=\left(\left(\frac{(e 1+e 2)}{2}\right) \times\left(\frac{D}{(h \times b)}\right)\right)
$$

where $e 1$, and $e 2$ are changes in length of the diagonal joint region in $\mathrm{mm}, D$ is initial diagonal length in $\mathrm{mm}, H$ is depth of the joint region in $\mathrm{mm}$, and $B$ is breadth of the joint region in $\mathrm{mm}$.

\section{Model Calculation}

Changes in length of the diagonal joint region: $(e 1)=$ $138 \mathrm{~mm}$.
Changes in length of the diagonal joint region: $(e 2)=$ $145 \mathrm{~mm}$.

Initial diagonal length: $D=148 \mathrm{~mm}$.

Depth of the joint region: $h=110 \mathrm{~mm}$.

So joint distortion $=0.2115 \mathrm{~mm}$.

Table 5 shows the joint shear stress versus joint distortion. In this while comparing the values of joint distortion, the beam-column joints made with $10 \%$ metakaolin $+30 \%$ quarry dust have less joint distortion compared to the beamcolumn joints made with ordinary concrete and concrete with seismic detailing.

\section{Conclusion}

Based on the experimental study, the following conclusions have been drawn. The exterior beam-column joint E21 and E22 with $10 \%$ metakaolin $+30 \%$ quarry dust performs better 
TABLE 5: Joint distortion.

\begin{tabular}{lcc}
\hline S. number & Specimen & Joint distortion $(\mathrm{mm})$ \\
\hline 1 & O1 & 0.2107 \\
2 & O2 & 0.2122 \\
3 & SS1 & 0.2113 \\
4 & SS2 & 0.2143 \\
5 & E11 & 0.2115 \\
6 & E12 & 0.2008 \\
7 & E21 & 0.2093 \\
8 & E22 & 0.2034 \\
9 & E31 & 0.2117 \\
10 & E32 & 0.2119 \\
\hline
\end{tabular}

than the beam-column joint with normal concrete as stated below:

(i) $10 \%$ higher load carrying capacity,

(ii) $15 \%$ more energy dissipation.

The exterior beam-column joint E31 and E32 (confinement joint) with $10 \%$ metakaolin $+30 \%$ quarry dust performs better than the beam-column joint with conventional concrete as stated below:

(i) very less joint distortion joint,

(ii) more ductility factor.

The metakaolin and quarry dust concrete specimens exhibited very little or no spalling of the concrete, whereas conventional concrete specimen showed extensive spalling of the concrete.

Metakaolin and quarry dust concrete increase the ultimate shear strength when compared to conventional reinforced concrete.

Metakaolin bridges the cracks in the concrete and restrains the crack propagation.

By using metakaolin, the spacing of hoops provided in the core of beam-column joint can be increased while maintaining ductile behavior. The practical difficulties in placing and compaction of the concrete in beam-column region can be avoided.

Thus metakaolin and quarry dust concrete can be seen as an appealing alternative to conventional confining reinforcement in all aspects.

\section{Conflict of Interests}

The authors declare that there is no conflict of interests regarding the publication of this paper.

\section{References}

[1] J. Anthony and B. S. Wolanski, Flexural Behaviour of Reinforced and Prestressed Concrete Beams Using Finite Element Analysis, Wisconsin, Milwaukee, Wis, USA, 2004.

[2] Patrick lucien minnaugh, The Experimental Behaviour of Steel Fibre Reinforced Polymer Retrofit Measures, University of Pittsburgh, 2006.
[3] J. N. Arlekar and C. V. R. Murty, "Future directions for capacity design of welded beam-to-column connections in steel seismic moment resisting frames," Structural Engineer, vol. 83, no. 13, pp. 36-41, 2005.

[4] L. Kutzing and G. König, Design Principle For Steel Fibre reinForced Concrete-A Fracture Mechanics Approach, Lacer, 1999.

[5] N. Ganesan and P. V. Indira, "Latex modified SFRC beamcolumn joints subjected to cyclic loading," Indian Concrete Journal, vol. 74, no. 7, pp. 416-420, 2000.

[6] S. R. Uma and M. Prasad, Seismic Behaviour of Beam Column Joints in Reinforced Concrete Moment Resisting Frames, IITKGSDMA-EQ31-Volume1.0, IITK-GSDMA project on building codes.

[7] S. R. Uma and S. K. Jain, "Seismic design of beam-column joints in RC moment resisting frames-review of codes," Structural Engineering and Mechanics, vol. 23, no. 5, pp. 579-597, 2006.

[8] F. Alameddine and M. R. Ehsani, "High-strength RC connections subjected to inelastic cyclic loading," ASCE Journal of Structural Engineering, vol. 117, no. 3, pp. 829-850, 1991.

[9] M. R. Ehsani and J. K. Wight, "Exterior reinforced concrete beam-to-column connections subjected to earthquake-type loading," Journal of the American Concrete Institute, vol. 82, no. 4, pp. 492-499, 1985.

[10] IS 13920, 1993, Indian Standard Ductile Detailing of Reinforced Concrete Structures Subjected to Seismic Forces-Code of Practice, 1993.

[11] IS 1893 (Part 1), 2002, Indian Standard Criteria for Earthquake Resistant Design of Structures, Part-1 General Provisions and Buildings, 2002.

[12] IS 456:2000, Indian Standard Plain and Reinforced Concrete Code of Practice, 2000.

[13] C. V. R. Murty, D. C. Rai, K. K. Bajpai, and S. K. Jain, "Effectiveness of reinforcement details in exterior reinforced concrete beam-column joints for earthquake resistance," ACI Structural Journal, vol. 100, no. 2, pp. 149-156, 2003. 

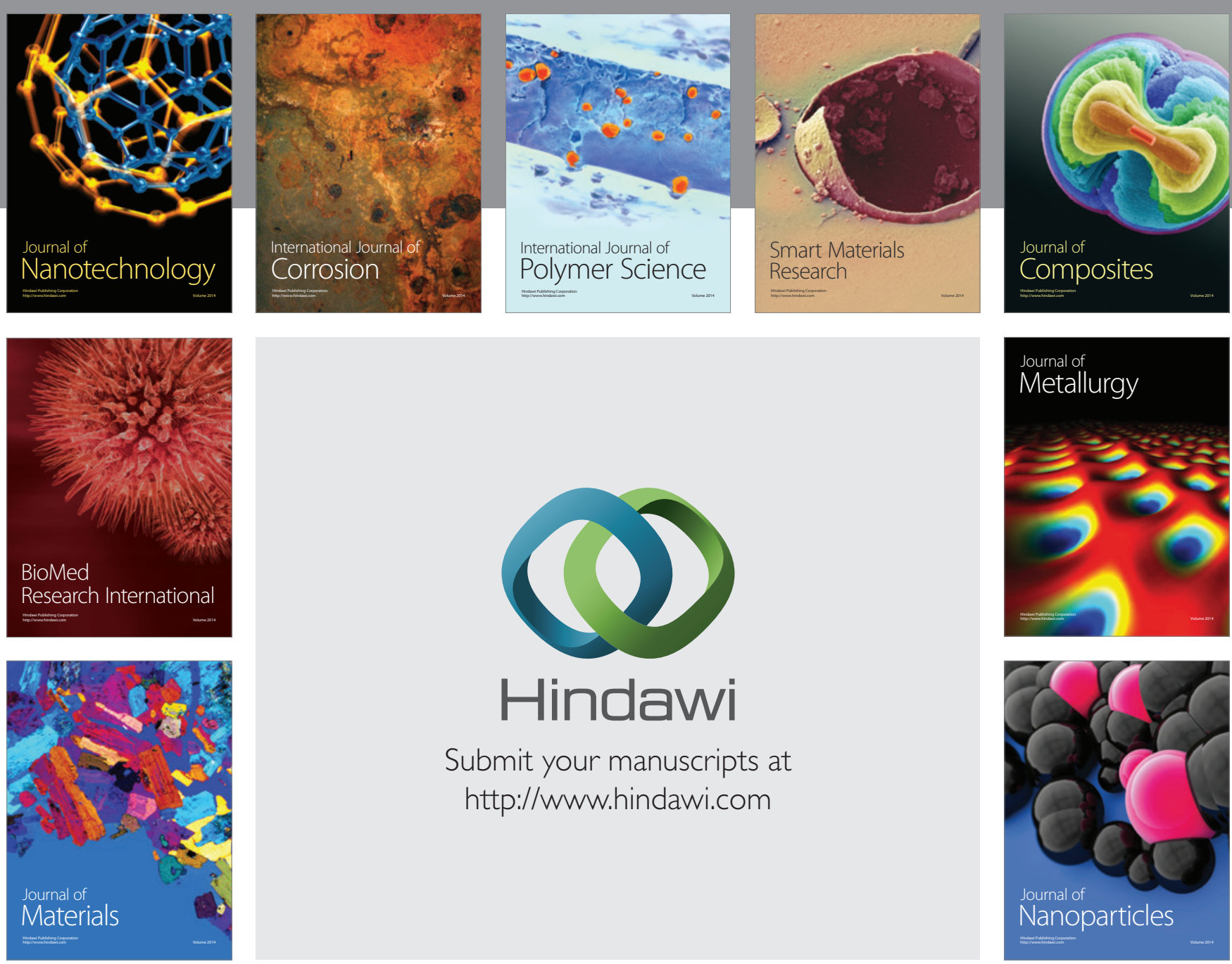

Submit your manuscripts at http://www.hindawi.com
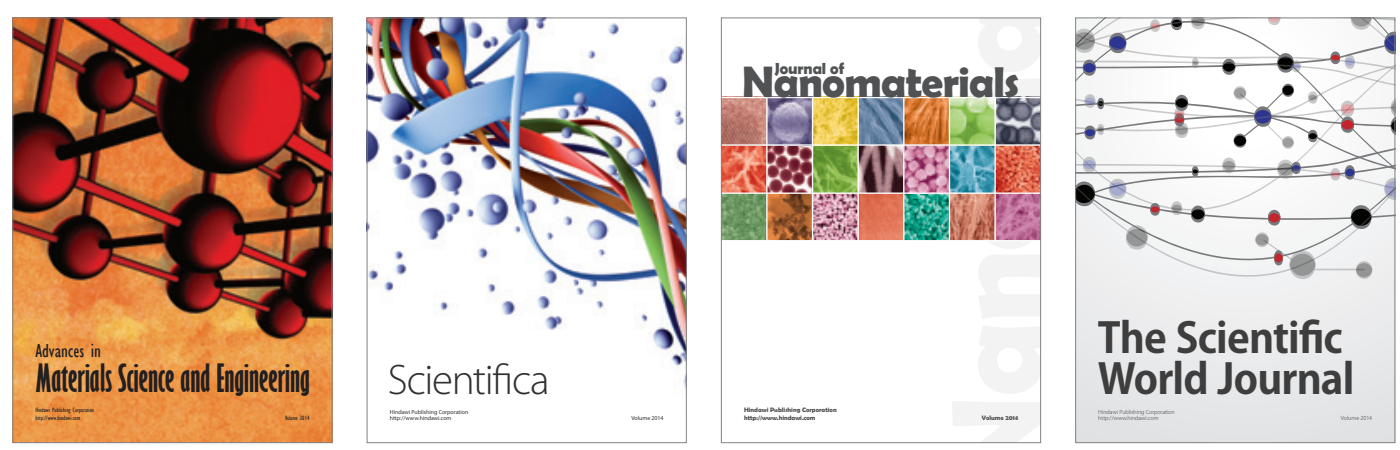

\section{The Scientific World Journal}
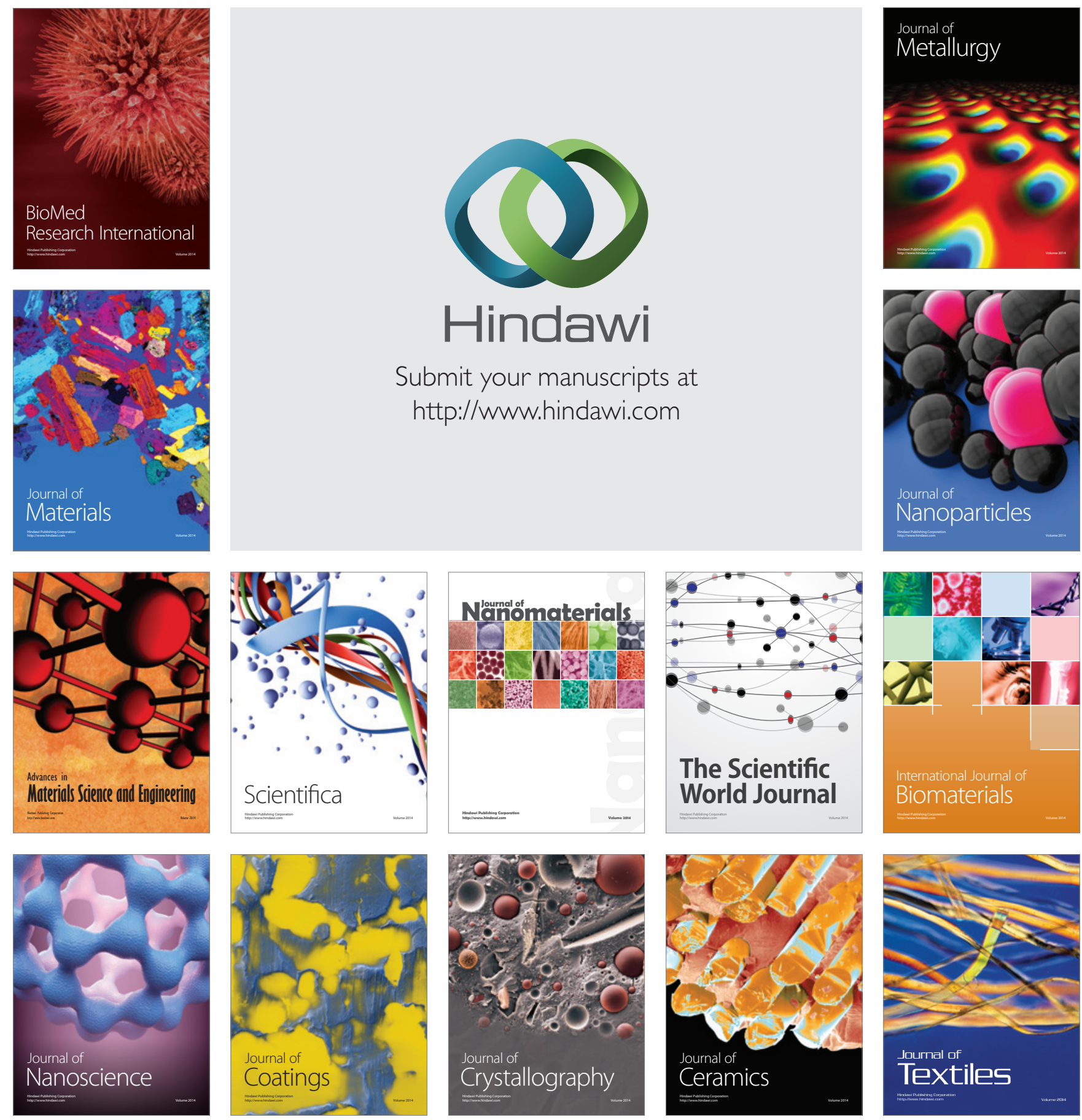